\title{
Climate Change and Disappearing Island States: Pursuing Remedial Territory
}

\author{
Emma Allen \\ PhD Candidate, Law School, University of Keele \\ e.l.allen@keele.ac.uk
}

\begin{abstract}
As at the start of 2018, at least eight low-lying Pacific islands have been found to have disappeared as a result of climate change induced rising sea levels and more seem likely in future to suffer the same fate. Because international law demands territory as a requirement of statehood, this could have implications for the affected states' continuation and the livelihood of the populations displaced. Scholars in recent years have therefore pointed to various strategies for the disappearing island community to maintain a territorial dimension. This article examines in particular the as yet largely uninvestigated option of pursuing remedial territory, i.e. territory transferred from responsible to injured states as redress for climate change induced deterritorialisation. Applying the rules on state responsibility, it considers whether at least some emitting third states may be obliged to provide a portion of their territory as reparation for the commission of an internationally wrongful act.
\end{abstract}

\section{Keywords}

Climate Change - Disappearing Island States - Remedial Territory - Statehood - State Responsibility 


\section{Introduction}

In May 2016, five of the Solomon Islands were found to have disappeared as a result of rising sea levels. ${ }^{1}$ By July 2017, further islands in Micronesia had suffered the same fate. ${ }^{2}$ These discoveries are thought to be the first, but by no means last, confirmation of the impact of climate change in the region. According to data published by the Intergovernmental Panel on Climate Change (IPCC), a number of small low-lying islands located in both the South Pacific and Indian Oceans stand to be submerged in the next fifty to one hundred years. ${ }^{3}$ This situation raises a number of important questions from an international law perspective, including whether the affected island communities - following the complete loss of their territorial basis - could cease to be states.

This is an important matter for a number of reasons. First, the possible physical disappearance of a sovereign state has never presented itself before. Any current consideration of so-called 'state disappearance' is within the context of state succession but these cases all presuppose that a successor state begins to exist on, or assumes control over, the territory of the previous state. ${ }^{4}$ Also, because international law accords primacy to states, ${ }^{5}$ with the loss of statehood comes the loss of a number of special privileges and attributes. For instance, only states have the right to invoke the jurisdiction of the International Court of Justice (ICJ) and only states can create the primary sources of international law. States are also the only actors to benefit from sovereign immunity and permanent sovereignty over natural resources and they are the only subjects of international law who can legitimately use force. Finally, the livelihood of entire populations will be placed at stake.

1 Simon Albert, Javier Leon, Alistair Grinham, John Church, Badin Gibbes and Colin Woodroffe, 'Interactions between Sea Level Rise and Wave Exposure on Reef Island Dynamics in the Solomon Islands', Environmental Research Letters, 11: 1-9 (2016).

2 Patrick Nunn, Augustine Kohler and Roselyn Kumar, 'Identifying and Assessing Evidence for Recent Shoreline Change Attributable to Uncommonly Rapid Sea Level Rise in Pohnpei, Federated States of Micronesia, Northwest Pacific Ocean', Journal of Coastal Conservation, 21: 719-730 (2017).

3 The most recent assessment report (AR5) can be found online at http://www.ipcc.ch/, accessed 30 August 2018.

4 See James Crawford, The Creation of States in International Law (Oxford: Oxford University Press, 2006), pp. 705-714.

5 See Martti Koskenniemi, 'What is International Law For?' in Malcolm Evans (ed.), International Law (Oxford: Oxford University Press, 2014), pp. 33-35; Gerry Simpson, 'Something to Do with States' in Anne Orford and Florian Hoffmann (eds.), The Oxford Handbook of the Theory of International Law (Oxford: Oxford University Press, 2016), pp. 566-570. 
In this article, the likely implications of climate change inundation on the legal status of the affected small island communities are therefore considered alongside some of the possible strategies for territorial sovereignty to be retained. The section following this introduction briefly outlines how the doctrine of statehood traditionally envisages the relationship between territory and sovereignty and the consequence of deterritorialisation on the continuity of the state. Following that, in the next section some of the main non-remedial strategies of territory retention are examined. These include the building of artificial islands, the appropriation of unclaimed land (terra nullius) and cooperation with third states. It is shown that, whilst theoretically available, these strategies are unlikely to succeed due to legal restrictions and practical limitations. The final section thus turns to consider the as yet largely uninvestigated option of pursuing remedial territory, i.e. territory transferred from responsible to injured states as redress for climate change induced deterritorialisation. Applying the rules on state responsibility - as codified by the 2001 Draft Articles on Responsibility of States for Internationally Wrongful Acts (ARSIWA $)^{6}-$ it is considered whether at least some emitting third states may be obliged to provide a portion of their territory as reparation for the commission of an internationally wrongful act. ${ }^{7}$

It is assumed as uncontroversial for the purposes of this article that some states have committed internationally wrongful acts - by failing to exert sufficient regulatory control over emission activities within their jurisdiction so as to meet their international obligations ${ }^{8}$ - and that their responsibility might be engaged as a result. The discussion is thus focused on the consequences of responsibility, in particular in terms of suitable reparation, rather than the general conditions necessary for responsibility to arise. The article's main argument is that, despite the presence of practical and juridical difficulties, the law as it currently stands does not prevent reparation in the form of remedial territory and in fact already provides for this form of redress in specific circumstances. It also contends that remedial territory presents the most suitable

6 ARsiwA, adopted by the International Law Commission at its 53rd Session, Official Records of the General Assembly, 56th Session, Supplement No. 10, UN Doc. A/56/10, Chapter IV.E.1 (2001).

7 Von Paepcke seems to be the only other scholar at present to have contemplated a possible claim to a new state territory, although without directly considering the rules of state responsibility in international law. See Frederik Von Paepcke, Statehood in Times of Climate Change: Impacts of Sea Level Rise on the Concept of States (Bern: Peter Lang Publishing, 2014), pp. 159-192.

8 As provided by the conventional climate change regime and the customary no harm rule. 
form of reparation in international law, legally and normatively, given the unavailability and inherent limitations of other types of redress.

\section{Territory, Sovereignty and the Law of Statehood}

In line with Article 1 of the 1933 Montevideo Convention on the Rights and Duties of States (Montevideo Convention), ${ }^{9}$ there is general consensus that the state as an international legal person should possess a defined territory, a permanent population, government and the capacity to enter into relations with other states. ${ }^{10}$ The problem for a disappearing island is that the dominant view among legal scholars is that the loss of any one of these constitutive elements will normally entail state extinction. ${ }^{11}$ More specifically for present purposes, it is generally thought that extinction will occur where a state ceases to possess any viable territorial base. For Marek, for instance, 'that a state would cease to exist if its territory were to disappear, e.g. an island which would become submerged, can be taken for granted. ${ }^{12}$ Likewise, for Craven, 'where the territory of a state becomes submerged by the sea, it should be possible to conclude that the state has ceased to exist.'. ${ }^{13}$ In the hope of avoiding this outcome, what follows therefore examines some of the different strategies available to the disappearing island community to find replacement territory and continue an existence in line with the traditional rules of statehood. There are of course also scholars, such as Burkett, who argue that the law is not so clear-cut and extinction of the international legal personality of a state following the loss of its material elements cannot be automatically inferred. ${ }^{14}$ However, the dominant view remains that there can be no state without territory and this will therefore be the assumption here.

91933 Montevideo Convention on the Rights and Duties of States (adopted 26 December 1933, entered into force 26 December 1934) 165 LNTS 19.

10 For further discussion of these requirements, see Crawford, The Creation of States in International Law, pp. 37-96.

11 Ibid., p. 671.

12 Krystyna Marek, Identity and Continuity of States in Public International Law (Paris: Librairie Droz, 1968), p. 7.

13 Matthew Craven, 'The Problem of State Succession and the Identity of States under International Law', European Journal of International Law, 9:142-162 (1998), p. 159. See also Malcolm Shaw, International Law (Cambridge: Cambridge University Press, 2014), p. 151.

14 Maxine Burkett, 'The Nation Ex-Situ: On Climate Change, Deterritorialised Nationhood and the Post-Climate Era', Climate Law, 2: 345-372 (2011). 


\section{Non-Remedial Strategies to Find Replacement Territory}

\section{Building Artificial Islands}

One of the first solutions often envisaged for a disappearing small island state to continue its existence in line with the traditional rules of statehood is the construction of artificial territory such as artificial islands. ${ }^{15}$ There is no doubt that this is technically a possibility and, if achieved, it would have the advantage of enabling the people to remain in their ancestral home base. The Maldives, for instance, has already built the artificial island of Hulhumale next to its capital Malé. Created by the dredging of sand from the ocean floor which has then been disgorged into a shallow lagoon, Hulhumalé encompasses over four hundred hectares of land which rise to a height of three metres above current sea level. It houses a hospital, schools, government buildings, commercial zones and residential areas for a total population of over forty thousand as of $2016 .^{16}$

The problem is that this sort of construction endeavour is extremely expensive and may thus in many cases turn out to be insurmountable. ${ }^{17}$ It is moreover not a solution that is guaranteed to last. Indeed, in light of the fact that even the multi-billion dollar World Islands in Dubai - an ambitiously constructed group of over three hundred man-made islands strategically positioned to form the shape of the countries of the globe - are sinking back into the sea from where they came, ${ }^{18}$ this may not be the most sustainable option. It is also important to be mindful of the potential for unwelcome environmental knockon effects. The creation of artificial islands stands to lead to serious marine environmental damage and the destruction of the marine ecosystem. In the 2016 South China Sea Arbitration, ${ }^{19}$ for instance, the tribunal had no doubt in concluding that 'China's artificial island building activities have caused devastating and long lasting damage to the marine environment' in the South China Sea. ${ }^{20}$ While it is not necessarily suggested that the same level of harm would

15 See, for instance, Jenny Grote Stoutenburg, Disappearing Island States in International Law (Leiden: Brill Publishers, 2015), p. 169; Abhimanyu Jain, 'The 21st Century Atlantis: The International Law of Statehood and Climate Change Induced Loss of Territory', Stanford Journal of International Law, 50: 1-52 (2014), p. 47.

16 For more information, see https://hdc.com.mv/hulhumale/, accessed 30 August 2018.

17 The cost of constructing Hulhumalé has run into hundreds of millions of dollars. See ibid.

18 See Richard Spencer, 'The World is Sinking: Dubai Islands Falling into the Sea', The Telegraph, 20 January 2011.

19 South China Sea Arbitration (Philippines v China) (2016) PCA Case No. 2013-19.

20 Ibid., para. 983. For more information generally, see paras. 976-983. See also Tim Stephens, 'The Collateral Damage from China's Great Wall of Sand: The Environmental Dimensions of the South China Sea Case', Australian Yearbook of International Law, 34: 41-52 (2016). 
come to be caused in the case of disappearing small island states which could (and likely would) take steps to minimise any negative environmental impacts, it is unlikely to be possible to limit the harm caused completely. The need to adapt to impending environmental damage cannot be used as an excuse to cause even more in its wake.

A further issue to be considered is whether an artificial island on its own could be relied upon to fulfil the requirement of a defined territory. ${ }^{21}$ For some scholars, such as Wong, this is very much contested under current international law. ${ }^{22}$ This is said to be evidenced by the 1978 decision of the Administrative Court of Cologne in Re Duchy of Sealand..$^{23}$ In this case, it was held that a British Second World War platform attached to the seabed off the coast of the United Kingdom (UK) did not fulfil the requirement of territory since territory must 'consist in a natural segment of the earth's surface' and 'come into existence in a natural way.' ${ }^{24}$ However, it must be underlined that this case actually dealt with an artificial installation as opposed to an artificial island and, moreover, this was not the only reason for the Court's refusal to recognise Sealand as a sovereign state. There was in addition the lack of a permanent population, the so-called nationals of the Principality not satisfying the criteria for community life. ${ }^{25}$

Potentially more relevant was the 1972 attempt to create the Republic of Minerva by building up a reef on the high seas in the vicinity of Tonga. ${ }^{26}$ This was at least more in line with the kind of artificial island likely to be constructed by a disappearing small island state, i.e. an island created by building up existing

21 This has been raised by several scholars. See, for instance, Catherine Blanchard, 'Evolution or Revolution? Evaluating the Territorial State Based Regime of International Law in the Context of the Physical Disappearance of Territory Due to Climate Change and Sea Level Rise', Canadian Yearbook of International Law, 53: 66-118 (2016), p. 94; Rosemary Rayfuse and Emily Crawford, 'Climate Change, Sovereignty and Statehood', Sydney Law School Research Paper No. 11/59, p. 7 .

22 Derek Wong, 'Sovereignty Sunk? The Position of Sinking States at International Law', Melbourne Journal of International Law, 14: 346-391 (2013), p. 384.

23 Re Duchy of Sealand (Administrative Court of Cologne) (1978) 80 ILR 683.

24 Ibid., pp. 685-686. For more information generally about the Principality of Sealand, see https://www.sealandgov.org/, accessed 30 August 2018.

25 Ibid., p. 687. Only very rarely has the case been made for the sovereign recognition of Sealand. See, for instance, Andrew Lyon, 'The Principality of Sealand and its Case for Sovereign Recognition', Emory International Law Review, 29: 637-671 (2015).

26 For more information, see Lawrence Horn, 'To Be or Not To Be: The Republic of Minerva and Nation Founding by Individuals', Columbia Journal of Transnational Law, 12: 520-556 (1973). 
territory so that it is permanently above water at high tide. Here again, admittedly, the view seems to have been taken that only those parts of the surface of the earth which have come into existence in a natural way can be recognised as constituting state territory. As noted by Crawford, for instance, 'artificial islands cannot form the basis for territorial states any more than can ships.' ${ }^{27}$ While this point may seem (at first glance) rather obvious and self-evident, however, on closer examination it is not. A ship is a very different thing than an artificial island. It moves, crosses borders, is not physically attached to any place on earth and cannot sustain life. The opposite is true of (at least some forms of) artificial islands. They do not pose the same jurisdictional and practical issues, they do not move and can, in principle, sustain life.

Clearly, this argument should not be interpreted as opening the floodgates generally to the existence of states based on artificial islands. The creation and continuity of states are distinct legal phenomena and it is important to recognise and maintain this distinction between the two. While a restrictive understanding of the territory requirement as a precursor to statehood prevents uncontrolled state proliferation, and was thus perhaps correctly construed in the two aforementioned examples, it plays no such role with regard to the continuation of pre-existing states. ${ }^{28}$ In realising this argument in practice, Gagain suggests that steps could be taken to collectively recognise that inundated states can continue to exist exclusively by means of artificial territory. ${ }^{29}$ For instance, if a majority of states representative of the international community as a whole voted in favour of a United Nations (UN) General Assembly resolution on the matter, their action could serve to highlight the presence of opinio juris which could ultimately help to accelerate the development of a new universal rule of customary international law. ${ }^{30}$

Key problems with this option nevertheless remain concerns about funding, sustainability and unwelcome knock-on environmental impacts. As such,

27 See James Crawford, 'Islands as Sovereign Nations', International and Comparative Law Quarterly, 38: 277-298 (1989), p. 279.

28 Jain, 'The 21st Century Atlantis', pp. 26-27.

29 Michael Gagain, 'Climate Change, Sea Level Rise and Artificial Islands: Saving the Maldives' Statehood and Maritime Claims through the Constitution of the Oceans', Colorado Journal of International Environmental Law and Policy, 23: 77-120 (2012), pp. 114-115. See also generally Grigoris Tsaltas, Tilemachos Bourtzis and Gerasimos Rodotheatos, 'Artificial Islands and Structures as a Means of Safeguarding State Sovereignty against Sea Level Rise: A Law of the Sea Perspective', paper presented at the 6th AbLos Conference, Monaco, October 2010.

30 Relevant guidance on this issue generally can be found in Texaco Overseas Petroleum Cov Libya (1978) 17 ILM 1. 
the construction of artificial islands cannot be relied upon for a definitive solution and other available options must also be explored.

\section{Appropriating Terra Nullius}

The second strategy that is open to a disappearing small island state to continue its existence in line with the traditional statehood rules is the appropriation of terra nullius. ${ }^{31}$ As noted by the Permanent Court of Arbitration (PCA) in the 1928 Island of Palmas Case, ${ }^{32}$ if unclaimed territory can be identified, an inchoate title may be completed by the effective occupation of the region found. ${ }^{33}$ According to the Permanent Court of International Justice (PCIJ) in the ${ }_{1933}$ Case Concerning the Legal Status of Eastern Greenland ${ }^{34}$ the concept of effective occupation requires some actual exercise or display of sovereignty. ${ }^{35}$ There are a wide range of acts that may constitute manifestations of this, usually classified according to the three traditional powers of a state, i.e. legislative, executive and judicial. ${ }^{36}$ The difficulty is identifying an area that is not currently under any state's jurisdiction as today this is not widely thought to exist in international law. ${ }^{37}$ The only unclaimed areas remaining are those regarded as res communis but these - encompassing outer space, the high seas and Antarctica - are intended to serve as a common resource to be shared by all of humanity and therefore are not generally capable of being reduced to sovereign control. ${ }^{38}$ Moreover, the most viable area of res communis is Antarctica and there is a cruelty inherent in relocating a community currently located on or near the equator to the coldest part of the world. ${ }^{39}$

\section{Cooperation with Third States}

The remaining strategies available to a disappearing small island state to find replacement territory involve cooperation with third states. They include, on the one hand, merger with another state less threatened by rising sea levels

31 Jain, 'The 21st Century Atlantis', p. 47.

32 Island of Palmas Case (United States $v$ The Netherlands) (1928) 2 RIAA 829.

33 Ibid., p. 846.

34 Case Concerning the Legal Status of Eastern Greenland (Denmark v Norway) (1933) PCIJ Rep Series A/B No.53.

35 Ibid., pp. $45^{-46 .}$

36 For further discussion, see Marcelo Kohen and Mamadou Hébié, 'Acquisition of Territory', Max Planck Encyclopedia of Public International Law, 2011, para. 31.

37 Jain, 'The 21st Century Atlantis', p. 47. The only way land belonging to no one is likely to become available now is that created through a volcanic eruption.

$38 \quad$ Ibid.

39 Ibid. 
and, on the other hand, the formal cession by another state of a replacement territorial base. These options will now briefly be considered in turn.

\section{Merger}

First of all, a disappearing island state could seek to merge with another state less threatened by rising sea levels. ${ }^{40}$ The main problem with this strategy is that, while it would address some of the problems associated with disappearance, such as finding a new home for the displaced islanders, it would not address the problem of the loss of statehood and is therefore unlikely to be viewed from a small island state perspective in a favourable light. ${ }^{41}$

Third states have also shown no appetite to accept the total populations of disappearing island communities and, as stands, there is no requirement for a protection response under international refugee law - as codified by the 1951 Convention Relating to the Status of Refugees (Refugee Convention) ${ }^{42}$ and the ${ }_{1967}$ Protocol Relating to the Status of Refugees (1967 Protocol) $)^{43}$ - which is generally viewed as an inappropriate framework for helping the environmentally displaced. Whereas Convention refugees, in line with Article 1(A)(2) Refugee Convention, flee persecution by their own government - or actors their government is unable or unwilling to protect them from - for reasons of race, religion, nationality, political opinion or membership of a particular social group, this is not the case of a person fleeing the effects of climate change. While, in an attempt to resolve this problem, scholars such as Docherty and Giannini have called for a new international treaty on climate change displacement to create a new class of refugee-like protected persons, ${ }^{44}$ others, most notably McAdam, argue that it is premature to push for a new global standard

40 This has been suggested by several scholars including Susin Park, 'Climate Change and the Risk of Statelessness: The Situation of Low-Lying Island States', Un HCR Legal and Protection Policy Research Series, PPLA/2011/04, p. 18; Rosemary Rayfuse, 'W(h)ither Tuvalu? International Law and Disappearing States', UNsw Law Research Paper No.2009-9, p. 8; Lilian Yamamoto and Miguel Esteban, Atoll Island States and International Law: Climate Change Displacement and Sovereignty (Berlin: Springer Publishing, 2014), p. 199.

41 Crawford, The Creation of States in International Law, p. 701.

$42195^{1}$ Convention Relating to the Status of Refugees (adopted 28 July 1951, entered into force 22 April 1954) 189 UNTS 137.

$43 \quad 1967$ Protocol Relating to the Status of Refugees (adopted 31 January 1967, entered into force 4 October 1967) 606 UnTs 267.

44 Bonnie Docherty and Tyler Giannini, 'Confronting a Rising Tide: A Proposal for a Convention on Climate Change Refugees', Harvard Environmental Law Review, 33: 349-403 (2009). 
setting agreement in this way. ${ }^{45}$ Apart from the clear unwillingness of states to develop such an instrument, it is contended that this kind of focus may distract from the distinct need for - and more feasible prospect of - new domestic and regional legislation to facilitate migration. ${ }^{46}$ In 2017 , for instance, the newly elected New Zealand government announced plans to create a special refugee visa for Pacific island residents who are forced to migrate because of rising sea levels. ${ }^{47}$ While this should no doubt be applauded and marks a turnaround for New Zealand which made international headlines in 2015 when the Supreme Court rejected a Kiribati man's claim for climate refugee status in Teitiota $v$ Chief Executive of the Ministry of Business, Innovation and Employment, ${ }^{48}$ the current proposal still only offers asylum to a limited number of individuals there are plans to start with one hundred places annually.9 ${ }^{49}$ There is also the question of whether being classified as refugees is desirable for the inhabitants of disappearing small island states. Far from automatically providing international protection, it is arguable that the use of the essentially negatively perceived concepts pertaining to refugee and forced migration law serves only to conclusively disempower the persons being displaced. ${ }^{50}$

\section{Cession}

The second and more appealing strategy from a disappearing small island state perspective is the formal cession of territory by a third state. ${ }^{51}$ This would allow statehood to persist because sovereignty over the ceded land would transfer in its entirety to the disappearing small island state which would then relocate

45 See Jane McAdam, 'Swimming against the Tide: Why a Climate Change Displacement Treaty is Not the Answer', International Journal of Refugee Law, 23: 2-27 (2011).

46 Ibid.

47 For more information, see Charles Anderson, 'New Zealand Considers Creating Climate Change Refugee Visas', The Guardian, 31 October 2017.

48 Teitiota $v$ Chief Executive of the Ministry of Business, Innovation and Employment [2015] NZSC 107. Several other climate change refugee cases have similarly been rejected. For more detailed analysis, see Jane McAdam, 'The Emerging New Zealand Jurisprudence on Climate Change, Disasters and Displacement', Migration Studies, 3: 131-142 (2015). See Nina Hall, 'Six Things New Zealand's New Government Needs To Do To Make Climate Refugee Visas Work', The Conversation, 30 November 2017.

5o Ibid. It has been suggested that the New Zealand government could instead consider expanding the existing Pacific Access Scheme. See https://www.immigration.govt.nz/ new-zealand-visas/apply-for-a-visa/about-visa/pacific-access-category-resident-visa/, accessed 30 August 2018.

51 Again, this has been suggested by several scholars including Park, 'Climate Change and the Risk of Statelessness', p. 18; Rayfuse, 'W(h)ither Tuvalu?', p. 7; Yamamoto and Esteban, Atoll Island States and International Law, p. 187. 
its population (or parts thereof) to the new territorial location, continuing its existence in line with the traditional rules of international law. The question is again how likely this strategy is to be achieved. While states are in theory well within their rights to cede portions of their territory, the chances of them actually doing so are rather small. Because there are few, if any, significant benefits to be gained from giving away land, the motivation to do this is weak. ${ }^{52}$

As an alternative, the possibility of purchasing land from another state has sometimes been suggested. First formulated in 2008 by then President of the Maldives, Mohamed Nasheed, the idea was taken up by then President of Kiribati, Anote Tong, in 2014. Kiribati concluded the purchase of two thousand hectares of land in Fiji (although the two parties involved in this transaction were the state of Kiribati and the Church of England as opposed to the states of Kiribati and Fiji as such). While so far noted that the purpose of the purchase is to develop coastal agriculture and thus enhance food security for Kiribati's people, the possibility that it may become a relocation site for the inhabitants of Kiribati has been openly discussed..$^{53}$ As noted by Crawford, however, 'the persistent analogy of territorial sovereignty to ownership of real property is misguided. ${ }^{54}$ The private purchase of territory is fundamentally different from the sovereign acquisition of land. While the purchase of territory gives the purchasing state private ownership rights, i.e. the right to occupy and extract natural resources or erect buildings, it does not give public sovereignty rights, i.e. the right to exercise sovereign jurisdiction, which are retained by the selling state itself. 55

In an attempt to resolve this matter, the remaining section will thus turn to consider whether a disappearing small island state may somehow be entitled to replacement sovereign territory under international law.

\section{The Concept of Remedial Territory}

In recent years there has been increasing recognition of a limited right to territory for states that are facing loss as a result of environmental factors - limited

\footnotetext{
52 Rayfuse, 'W(h)ither Tuvalu?', p. 8; Yamamoto and Esteban, Atoll Island States and International Law, p. 187.

53 For more information, see Laurence Caramel, 'Besieged by the Rising Tides of Climate Change, Kiribati Buys Land in Fiji', The Guardian, 1 July 2014.

54 Crawford, The Creation of States in International Law, p. 717.

55 Alexandra Harrington, 'Anomalies of Territory: Examining the Relationship between Territory, Sovereignty and Statehood', PhD Thesis, McGill University, 2014, p. 137.
} 
because it is still generally accepted that the state that currently holds sovereignty over the territory in question must be willing to give it up. ${ }^{56}$ In seeking here to remedy this absence of compulsion on the part of third states, as noted, discussion will be shifted to the option of pursuing remedial territory, i.e. territory transferred from responsible to injured states as redress for climate change induced deterritorialisation. Applying the rules on state responsibility - as codified by ARSIWA - this section considers whether at least some emitting third states may be obliged to provide a portion of their territory as reparation for the commission of an internationally wrongful act. As mentioned, it is assumed as uncontroversial for the purposes of this article that some states have committed internationally wrongful acts - by failing to exert sufficient regulatory control over emission activities within their jurisdiction so as to meet their international obligations - and that their responsibility might be engaged as a result. The discussion is thus focused on the consequences of responsibility, in particular in terms of suitable reparation, rather than the general conditions necessary for responsibility to arise.

There are two core consequences that flow as a matter of law from the commission of an internationally wrongful act. First, in accordance with ARsiWA Article 30, the responsible state is obliged to cease the wrongful conduct - in this case to bring greenhouse gas emissions back in line with its international obligations $5^{57}$ - and second, in accordance with ARsıwA Article 31, full reparation must be made for any injury caused. ${ }^{58} \mathrm{~A}$ disappearing island state could therefore potentially demand reparation provided a few important issues are addressed.

56 Alexandra Harrington, 'Is there a Right to Territory in International Law?' in James Smith (ed.), Property and Sovereignty: Legal and Cultural Perspectives (Abingdon: Routledge, 2016).

57 The continued duty of the responsible state to perform the obligation breached is provided in ARsIWA Article 29.

$5^{8}$ This principle was established by the PCIJ in the 1927 Case Concerning the Factory at Chorzów. See Case Concerning the Factory at Chorzów (Germany v Poland) (Jurisdiction) (1927) PCIJ Rep Series A No.9, p. 21. While, during the drafting of ARsiwA, some members of the International Law Commission (ILC) raised concerns about the requirement to make 'full' reparation, it was ultimately decided not to include any term qualifying the expression and the original wording was retained. For further discussion, see James Crawford, State Responsibility: The General Part (Cambridge: Cambridge University Press, 2014), pp. 481-485. See also Benoit Mayer, 'Climate Change Reparations and the Law and Practice of State Responsibility', Asian Journal of International Law, 7: 185-216 (2017) for a more recent (re)consideration of the matter. 
The first issue is whether reparation can be demanded before injury has been suffered. While injury is not strictly a condition for the existence of an internationally wrongful act and the invocation of state responsibility (only if the relevant primary obligation requires injury will injury have to be shown before any issue of responsibility is raised) nor is it a condition for the obligation of cessation, it is a requirement under ARsiwA Article 31. No notion of 'legal injury', i.e. injury arising from the mere fact of the breach of an international legal norm, is included within the Article 31 concept of injury.59 This means that, until such time as inundation occurs, which in most instances has yet to happen, reparation may not be claimed as the injury has yet to be suffered for which it is due. In some instances, admittedly, inundation has already occurred and, as noted in the introduction, several low-lying islands have now started to disappear. However, this currently remains the exception rather than the rule.

Having said this, there is no convincing reason why the judicial protection of an endangered state should be narrowed down to a scenario where its territory has already been lost. As discussed, such a country clearly cannot wait until the anticipated injury occurs because by then it will cease to exist and thus lose the capacity to make a claim under international law. From the perspective of scholars such as Von Paepcke, this leads to the conclusion that the claim of a disappearing island has to exist as soon as its future submergence can be demonstrated as a matter of scientific fact. ${ }^{60}$ On the basis of the most recent evidence available, it is arguable that a compelling case can already be made in this regard. ${ }^{61}$

A further issue relates to the causal link between the internationally wrongful act and the prospective injury. According to Voigt, the causal analysis can usefully be broken down into several component parts. ${ }^{62}$ First, general causation refers to a link between an activity and the general outcome. Since the first report of the IPCC in 1990, there has been almost uniform scientific consensus that increasing greenhouse gas emissions have led to an increase in average temperature which has led to sea level rise which will in all probability lead to

59 For further discussion, see Brigitte Stern, 'A Plea for Reconstruction of International Responsibility Based on the Notion of Legal Injury' in Maurizio Ragazzi (ed.), International Responsibility Today: Essays in Memory of Oscar Schachter (Leiden: Brill Publishers, 2005).

6o Von Paepcke, Statehood in Times of Climate Change, p. 171.

61 See IPCC AR5.

62 Christina Voigt, 'State Responsibility for Climate Change Damages', Nordic Journal of International Law, 77: 1-22 (2008), p. 15. See also Roda Verheyen, Climate Change Damage and International Law: Prevention Duties and State Responsibility (Leiden: Brill Publishers, 2005), p. 257. 
disappeared small island states. ${ }^{63}$ While it is difficult to ascertain when a piece of evidence would be accepted by an international court or tribunal as meeting the required standard of proof to establish causation, there is no evidence that full proof would be necessary and certainty ranges like those employed would likely suffice. ${ }^{64}$ This will not therefore be the subject of further discussion here. Focus will instead be placed on the second matter of specific causation, i.e. proving that a specific activity has caused a specific resulting harm.

According to the 'but for' test, the most widely used test under the current law, ${ }^{65}$ a defendant will be liable only if the claimant's damage would not have occurred but for what he or she has done. The main problem with this test is that it cannot cope well in all situations and may sometimes lead to absurd results. In the context of climate change inundation, for example, but for the emissions of any single state, the territories of many small island states would still likely be submerged. This seems to suggest that, due to manifold causes, it is impossible to ascertain liability for this specific climate change harm. ${ }^{66}$ In an attempt to resolve this problem, scholars in recent years have started to consider alternative approaches for establishing causation in multiple responsibility claims. According to Plakokefalos, the most convincing alternative is the so-called 'necessary element of a sufficient set' (NESs) test. ${ }^{67}$ This test posits that, while each emitting state can truthfully say that its individual emissions were not independently sufficient to cause the resulting harm, they were all necessary elements of an overall set that were. ${ }^{68}$ Assuming concerns as to the extent of reparation that may be pursued from any one opponent can also be

63 See IPCC AR5 as the most recent report.

64 For further discussion, see Verheyen, Climate Change Damage and International Law, pp. 26o-263; Voigt, 'State Responsibility for Climate Change Damages', p. 16.

65 This has been noted by several scholars including Ilias Plakokefalos, 'Causation in the Law of State Responsibility and the Problem of Overdetermination: In Search of Clarity', European Journal of International Law, 26: 471-492 (2015), p. 477; Verheyen, Climate Change Damage and International Law, p. 253; Voigt, 'State Responsibility for Climate Change Damages', p. 15; Von Paepcke, Statehood in Times of Climate Change, p. 81.

66 Ibid.

67 Plakokefalos, 'Causation in the Law of State Responsibility and the Problem of Overdetermination', p. 477.

68 Ibid. Similar approaches have likewise been propounded by Verheyen, Voigt and Von Paepcke. See Verheyen, Climate Change Damage and International Law, p. 257; Voigt, 'State Responsibility for Climate Change Damages', p. 16; Von Paepcke, Statehood in Times of Climate Change, p. 82. 
overcome using the principles of shared responsibility, ${ }^{69}$ it may therefore be said that the presence of multiple causes does not pose a hurdle that cannot be overcome.

The next consideration is whether reparation encompasses territory. ARSIWA Article 34 sets out the forms of reparation which, separately or in combination, will discharge the obligation to make full reparation for the injury caused by the internationally wrongful act. These are restitution, compensation and satisfaction. The likely suitability of each of these will now be considered in turn.

In terms of whether restitution, the first of the forms of reparation available under ARSIWA Article 35, encompasses the provision of a new state territory, it is not clear that this is so. Traditionally understood, restitution involves the re-establishment as far as possible of the status quo ante, that is, the situation which existed prior to the commission of the internationally wrongful act. In its simplest form, it thus involves such conduct as the release of persons wrongfully detained or the return of property wrongly seized..$^{70}$ In the context of climate change inundation, unfortunately, this cannot be achieved. The tide cannot, as it were, be reversed. And even if it could, submerged land would likely have become entirely uninhabitable due to land contamination by salted seawater and the destruction of all existing ecosystems.

In many ways, this is more akin to a situation where restitution is excluded because it is materially impossible in line with ARsiwA Article 35(a). While there are few cases in international courts and tribunals, according to the ARSIWA commentary, relevant examples include those where property to be returned or restored has been permanently lost or destroyed. ${ }^{71}$ It could potentially be argued, based on the non-traditional circumstances at hand, that exception be made and alternative territory be considered appropriate in terms of restitution. Indeed, to quote Von Paepcke, 'the granting of a new state territory is the most appropriate legal consequence to establish not the status quo

69 This involves the victim pursuing full reparation from any responsible state which can then in turn require reimbursement from the other states that have also contributed to the resulting harm. See Pierre d'Argent, 'Reparation, Cessation, Assurances and Guarantees of Non-Repetition' in André Nollkaemper and Ilias Plakokefalos (eds.), Principles of Shared Responsibility in International Law: An Appraisal of the State of the Art (Cambridge: Cambridge University Press, 2014). See also André Nollkaemper, 'Shared Responsibility in International Law', un Audiovisual Library of International Law, January 2016.

70 ARsiwa Commentary, adopted by the International Law Commission at its 53rd Session, Official Records of the General Assembly, 56th Session, Supplement No.10, UN Doc. A/56/10, Chapter IV.E.2 (2001), Article 35, para. 1 .

$71 \quad$ Ibid., Article 35, para. 8. 
ante but the closest scenario thereto. ${ }^{72}$ The question is how likely this argument is to be successful or whether, as is the contention of this article, there are other, better, strategies that could be pursued.

The second form of reparation available is compensation for the damage caused. According to ARSIWA Article 36 and the related ARSIWA commentary, this generally consists of a monetary payment and may therefore again appear not to be relevant to the case at hand. ${ }^{73}$ Indeed, the commentary gives a large number of examples of situations in which compensation has been paid across a wide range of disputes, including environmental damage. ${ }^{74}$ This was added to further in the 2018 Case Concerning Certain Activities carried out by Nicaragua in the Border Area ${ }^{75}$ in which the ICJ for the first time issued an order on monetary compensation for environmental damage in respect of unlawful activities carried out by Nicaragua in Costa Rican territory since 2010. In at least some instances, however, international law does also seem to recognise the possibility of compensation in non-monetary form. There is a notion in the 2007 United Nations Declaration on the Rights of Indigenous Peoples (UNDRIP), ${ }^{76}$ for example, of replacement territory for confiscated land that cannot be returned. Specifically, it is provided in Article 28 that:

1. Indigenous peoples have the right to redress, by means that can include restitution or, when this is not possible, just, fair and equitable compensation, for the lands, territories and resources which they have traditionally owned or otherwise occupied or used, and which have been confiscated, taken, occupied, used or damaged without their free, prior and informed consent.

2. Unless otherwise freely agreed upon by the peoples concerned, compensation shall take the form of lands, territories and resources equal in quality, size and legal status or of monetary compensation or other appropriate redress.

72 Von Paepcke, Statehood in Times of Climate Change, p. 169.

73 See ARsiwa Commentary, Article 36, para. 4.

74 Ibid., Article 36, paras. 13-15.

75 Case Concerning Certain Activities carried out by Nicaragua in the Border Area (Costa Rica $v$ Nicaragua) (Compensation owed by Nicaragua to Costa Rica) (2018) available online at https://www.icj-cij.org/files/case-related/150/150-20180202-JUD-01-0o-EN.pdf, accessed 30 August 2018.

76 UNDRIP, United Nations General Assembly Resolution 61/295, Un Doc. A/RES/61/295, 2 October 2007. 
The notion of replacement territory has also sometimes been referred to in the case law. In the 2010 Endorois case, ${ }^{77}$ for instance, the Kenyan government evicted the Endorois people, a traditional pastoralist community, from their homes at Lake Bogoria in central Kenya to make way for tourist facilities and a national reserve. The African Commission on Peoples' and Human Rights ruled that the Endorois' eviction from their traditional land violated their human rights and called on Kenya to provide the Endorois with restitution of their lands or other lands of equal extension and quality as redress. ${ }^{78}$

The key point then is that there already exists both a recent international instrument and international case law which recognise the concept of remedial territory as an appropriate form of reparation. What is being suggested for the disappearing small island community is not something completely novel, but already existing and accepted in international law. Remedial territory is chosen as an appropriate form of reparation when restitution is unavailable and when compensation will not suffice.

In the context of indigenous peoples, the reason that monetary compensation is usually inappropriate to ensure effective redress is that, because of the significance of their territory to them, in the absence of restitution, no amount of money can restore the often profound sense of collective spiritual identity and cultural wellbeing that has otherwise been dismantled - only the provision of a replacement territorial base can begin to repair the order by at least enabling it to continue its existence in the usual way. ${ }^{79}$ For the community of disappearing small island states, in the absence of restitution, no amount of money will make up for the ensuing loss of statehood. There is no money which can make up for the loss of what is essentially an immaterial legal status (though the loss of this immaterial status obviously has deep material consequences for the people involved). In addition, it can also be said that, in some parts of the Pacific region, land is vitally important and for many cultures is

77 Centre for Minority Rights Development (Kenya) and Minority Rights Group International on behalf of Endorois Welfare Council v Kenya, 276/2003, African Commission on Human and Peoples' Rights, 4 February 2010.

78 See ibid., para. 209.

79 For further discussion, see Committee on the Rights of Indigenous Peoples, 'Rights of Indigenous Peoples: Committee Report' in International Law Association, Report of the 74th Conference held in The Hague, August 2010, pp. 39-43. This was a specialised group of experts appointed by the International Law Association (ILA) and tasked with providing authoritative clarification, elucidation and guidance in respect of the UNDRIP provisions. See also Federico Lenzerini, 'Reparations, Restitution and Redress' in Jessie Hohmann and Marc Weller (eds.), The UN Declaration on the Rights of Indigenous Peoples: A Commentary (Oxford: Oxford University Press, 2018). 
inseparable from those to whom it belongs. For the Marshallese, for example, the land possesses a sacred or spiritual quality and is at the very root of their existence in the world..$^{80}$ The situation caused by climate change will thus also result in considerable loss of spirituality and culture. It is by no means suggested that being vitally important and culturally significant is as strong as the link of indigenous peoples to their ancestral territories (though at least some of the members of the displaced communities may be considered as indigenous peoples). The argument made here is by analogy - the primary reason for the granting of territory will be the loss of statehood, but it is also useful to be mindful of the value of the land to the populations involved.

Admittedly, there are still a number of problems that need to be resolved in order to make territorial compensation practically viable. One substantial matter is that, should an already inhabited area of land be granted as compensation, it is important to consider the implications of transferring a populated piece of territory to a drowning state. To best protect the rights of the original inhabitants, Dietrich and Wündisch propose two alternative solutions. On the one hand, they may choose to resettle on the downscaled territory of their original state. In this case, they would be entitled to full financial compensation for all associated costs. On the other hand, they could decide not to leave their current place of residence but would then have to accept the authority of a foreign state. In this case, the cession of territory has to be subject to the condition that the new authority credibly commits itself to respect the rights of the original inhabitants and they may also have to be granted citizenship after a certain amount of time. ${ }^{81}$

For those that choose the first option, i.e. decide to resettle, the reason that financial compensation is here justifiable when it was not above is that, while the political units of disappearing island communities lose all of their territory and hence their statehood which money cannot adequately compensate, this is not the case of the political units in the areas where the drowning island states are to be re-established. They lose only part of their territories and not their state such that financial compensation is here adequate to provide redress. It is also already accepted that the right to housing has certain exceptions, i.e. it is not an absolute right, and that there are certain circumstances in which the state has the right to displace people. Indeed, while in its General

8o For more information generally on the meaning of land in Pacific islands, see John Campbell, 'Climate Induced Community Relocation in the Pacific: The Meaning and Importance of Land' in Jane McAdam (ed.), Climate Change and Displacement: Multidisciplinary Perspectives (London: Bloomsbury Publishing, 2010), pp. 6o-64.

81 Frank Dietrich and Joachim Wündisch, 'Territory Lost: Climate Change and the Violation of Self-Determination Rights', Moral Philosophy and Politics, 2: 83-105 (2015), pp. 100-101. 
Comment No. 4, the Committee on Economic, Social and Cultural Rights (CESCR) considered that instances of forced eviction are prima facie incompatible with the right to adequate housing provided in Article 11(1) of the 1966 International Covenant on Economic, Social and Cultural Rights (ICESCR), ${ }^{82}$ it was conceded that they could be justified in the most exceptional circumstances and in accordance with the relevant principles of international law. ${ }^{83}$ These conditions are likely to be satisfied in the specific context discussed here. ${ }^{84}$

In accordance with ARSIWA Article 37, satisfaction is the third and final form of reparation available. It is not a standard form of reparation, however, in the sense that in many cases the injury caused by an internationally wrongful act of a state may, by means of restitution and/or compensation, already have been fully repaired. Indeed, the rather exceptional character of the remedy of satisfaction, and its relationship to the principle of full reparation, are emphasised by the phrase 'insofar as the injury cannot be made good by restitution or compensation' in ARsiwA Article 37(1). In that this is likely to be the situation in the case in question, this will not therefore be the subject of further discussion here. ${ }^{85}$

As a final matter, account needs to very briefly be taken of the contribution to the injury by the injured state. This issue is regulated by ARsIWA Article 39 which provides that, where the claimant has contributed to the resulting harm, this may affect the extent of the reparation due. The key point to note is that a contribution is only relevant if it is 'wilful' or 'negligent', i.e. shows a manifest lack of due care. While it is true that most disappearing island states have also emitted greenhouse gases to some extent, they are believed to have jointly contributed on average less than one percent of the current greenhouse gases in the atmosphere so it is unlikely this requirement would be deemed to be fulfilled. ${ }^{86}$

\section{Conclusion}

This article has considered the plight of the community of disappearing small island states and the fact that, under existing law, without territory they may

\footnotetext{
821966 International Covenant on Economic, Social and Cultural Rights (adopted 16 December 1966, entered into force 3 January 1976) 993 UNTS 3.

83 See CESCR, General Comment No.4, Un Doc. E/1992/23, 13 December 1991, para. 18.

84 For further discussion, see CESCR, General Comment No.7, un Doc. E/1998/22, 20 May 1997. See also Dietrich and Wündisch, 'Territory Lost', pp. 101-102.

85 For further discussion, see Crawford, State Responsibility, pp. 527-531.

86 See IPCC AR5.
} 
be said to have ceased to exist. In the hope of avoiding this outcome, some of the different strategies that could be employed to find replacement territory and thus continue an existence in line with the traditional rules of statehood have been discussed. It has been shown that, while none of the non-remedial strategies available are likely to provide a definitive solution, there is scope for a claim to remedial territory under international law.

The main question outstanding is whether it is possible for such a claim to be effectively implemented. Perhaps the most difficult matter is that of jurisdiction and the availability of a suitable forum for a liability claim. As things stand, the possibility that a court or tribunal considers a state responsibility claim is somewhat limited by the dependency in international law on sovereign states' readiness (in accordance with the fundamental principle of state sovereignty) to submit their behaviour to scrutiny. They are able to decide for themselves whether or not they consent to a given court's rule and, as noted by several scholars, most defendant states are unlikely to agree to be tried. ${ }^{87}$ Admittedly, seventy three states (including several large emitters) have made declarations under Article $36(2)$ ICJ Statute ${ }^{88}$ recognising as compulsory without special agreement the jurisdiction of the ICJ.$^{89}$ This could prove useful for those disappearing island states that, in line with the principle of reciprocity, have likewise made Article 36(2) declarations. While currently quite limited in number, there is nothing to stop other affected communities in the future from taking similar steps. The main difficulty, should they do this, is the fact that states are free to append to their declarations any type of reservations. Even to the extent the declarations made to date are not a bar to jurisdiction, therefore, it is widely recognised that they can and often will be amended and even withdrawn entirely to prevent litigation before a case has commenced and there has been a long history of this practice taking place. ${ }^{90}$

87 Laura Horn, 'Is Litigation an Effective Weapon for Pacific Island Nations in the War against Climate Change?', Asia Pacific Journal of Environmental Law, 12: 169-202 (2009), p. 197; Rebecca Jacobs, 'Treading Deep Waters: Substantive Law Issues in Tuvalu's Threat to Sue the United States in the International Court of Justice', Pacific Rim Law and Policy Journal, 14: 103-128 (2005), p. 115; Voigt, 'State Responsibility for Climate Change Damages', p. 21; Von Paepcke, Statehood in Times of Climate Change, p. 179.

88 Annexed to the Charter of the United Nations (adopted 26 June 1945, entered into force 24 October 1945) 1 UNTS XVI (UN Charter).

89 For a complete list, see http://www.icj-cij.org/en/, accessed 30 August 2018.

9o See, perhaps most notably, the Case Concerning Military and Paramilitary Activities in and against Nicaragua (Nicaragua v United States) (Jurisdiction of the Court and Admissibility of the Application) [1984] ICJ Rep 392. For further consideration of the impacts of this case on later optional clause practice, see Brian McGarry, 'Nicaragua's Impacts 
Following the 2016 Cases Concerning Obligations Concerning Negotiations Relating to Cessation of the Nuclear Arms Race and to Nuclear Disarmament, ${ }^{91}$ it is likewise important not to take for granted the willingness of international courts and tribunals such as the ICJ to pronounce on politically charged questions, let alone 'super wicked' problems such as climate change. Here, the contention by the Marshall Islands that the three respondent states - India, Pakistan and the UK - had breached their disarmament obligations never ultimately came to be decided on the ground that, as at the date of the respective applications, there existed 'no dispute. ${ }^{92}$ While, admittedly, caution is warranted before jumping to conclusions and there are potentially a wide range of factors that might explain a judge's vote or reasoning in any given case, these considerations alone are unlikely to eradicate concerns that the majority simply found new technical arguments to avoid dealing with a matter that they had absolutely no desire to entertain. ${ }^{93}$

A better option may therefore be to consider an alternative forum that could address the crisis and ensure remedies to disappearing small island states. ${ }^{94}$ For instance, it could be that the concept of remedial territory becomes a part of the loss and damage mechanism that is now included in Article 8 of

on Optional Clause Practice' in Edgardo Sobenes Obregon and Benjamin Samson (eds.), Nicaragua Before the International Court of Justice: Impacts on International Law (Berlin: Springer Publishing, 2017).

91 Case Concerning Obligations Concerning Negotiations Relating to Cessation of the Nuclear Arms Race and to Nuclear Disarmament (Marshall Islands v India) (Jurisdiction and Admissibility) [2016] ICJ Rep 255; Case Concerning Obligations Concerning Negotiations Relating to Cessation of the Nuclear Arms Race and to Nuclear Disarmament (Marshall Islands v Pakistan) (Jurisdiction and Admissibility) [2016] ICJ Rep 552; Case Concerning Obligations Concerning Negotiations Relating to Cessation of the Nuclear Arms Race and to Nuclear Disarmament (Marshall Islands v United Kingdom) (Jurisdiction and Admissibility) [2016] ICJ Rep 833.

92 For further consideration generally of the arguments made by the majority, see ibid. See also the separate opinions of President Abraham and Judges Bhandari, Donoghue, Gaja, Owada and Xue.

93 See, for instance, Michael Becker, 'The Dispute That Wasn't There: Judgments in the Nuclear Disarmament Cases at the International Court of Justice', Cambridge International Law Journal, 6: 4-26 (2017), pp. 20-21; Andrea Bianchi, 'Choice and (the Awareness of) its Consequences: The ICJ's Structural Bias Strikes Again in the Marshall Islands Case', AJIL Unbound, 111: 81-87 (2017); Nico Krisch, 'Capitulation in The Hague: The Marshall Islands Cases', EJIL: Talk!, 10 October 2016.

94 Pratheek Reddy, 'Sinking Small Island Nations: Calls for a Lifeboat', Environmental Law Reporter, 47: 10576-10579 (2017), p. 10578. 
the Paris Agreement. ${ }^{95}$ The question is how to create the necessary political pressure and third party guidance required to reinvigorate this mechanism. As stands, any notion of liability and compensation has been explicitly ruled out. ${ }^{96}$ Seeking an ICJ advisory opinion on state responsibility for climate change impacts could potentially promote international efforts to come to an agreement. ${ }^{97}$ Indeed, like the campaign initiated in 2011 by the Pacific island state of Palau that, pursuant to Article 96 UN Charter, the UN General Assembly request an advisory opinion from the ICJ concerning the duties of states to ensure that greenhouse gas emissions from their territory do not harm other states, there may be benefit in renewed efforts to invite the ICJ to advise on the legal responsibility of the largest emitters for climate change. ${ }^{98}$ In the event a request is made, admittedly, should the ICJ still then choose to deny it or adopt a restrictive approach on the matter, a ruling may be in danger of reducing the pressure on states. Again, as seen from the aforementioned discussion of the recent Marshall Islands claims, this is not entirely unimaginable. However, the general perception seems to be that the ICJ would be more willing to provide an advisory opinion than to decide a contentious case. ${ }^{99}$

In the interim, nevertheless, alongside remedial strategies to find replacement territory, it is necessary to consider the possibility that statehood might now exist (or at least that some states might continue) in other, more

95 Paris Agreement (adopted 12 December 2015, entered into force 4 November 2016).

96 See the Decision of the Conference of the Parties accompanying the Paris Agreement, para. 51, available online at https://unfccc.int/resource/docs/2015/cop21/eng/10a01.pdf, accessed 30 August 2018.

97 See Article 65 ICJ Statute. Scholars to have advocated the value of an advisory opinion in advancing the climate change cause include Daniel Bodansky, 'The Role of the International Court of Justice in Addressing Climate Change: Some Preliminary Reflections', Arizona State Law Journal, 49: 1-24 (2017); Philippe Sands, 'Climate Change and the Rule of Law: Adjudicating the Future in International Law', Journal of Environmental Law, 28: 19-35 (2016). For further consideration generally of the applicability of state responsibility despite practical obstacles precluding its implementation, see Benoit Mayer, 'State Responsibility and Climate Change Governance: A Light through the Storm', Chinese Journal of International Law, 13: 539-575 (2014).

98 For more information on the Palau initiative, see Douglas Kysar, 'Climate Change and the International Court of Justice', Yale Law School Research Paper No.315. This was ultimately left dormant because of threats of reprisal by large emitters. While the fear of retaliation has the potential to stymie future efforts as well, as seen, pressing for this could now prove imperative.

99 This is even so in the context of the Marshall Islands cases. See Daniel Joyner, 'My Reaction to the Dismissal of the Marshall Islands Cases by the ICJ', Arms Control Law, 5 October 2016. 
non-traditional and non-territorial forms. As mentioned, there are already scholars who argue that extinction of the international legal personality of a state following the loss of its material elements cannot be automatically inferred. Burkett, perhaps most notably, has argued that island states could survive as 'nations ex-situ'.100 This would allow for their continued existence in perpetuity despite their populations eventually being spread across the globe. There can be no doubt that this kind of creative (re)interpretation of existing legal doctrine is worth pursuing further. ${ }^{101}$ The inability of the international legal order to prevent blameless victims from suffering significantly negative consequences raises persistent questions about the effectiveness and legitimacy of the system as it currently stands. Only by accepting that an island state threatened with the disappearance of its territory may continue to exist in a deterritorialised form can, and should, its international legal personality be preserved in spite of a rising tide.

100 Burkett, 'The Nation Ex-Situ'.

101 This will in fact be the focus of some of the author's own forthcoming work. 